\title{
A MAGYAR INTERNET TÖRTÉNETEI
}

A Tófalvy Tamás által szerkesztett könyv a második kötete annak a sorozatnak, amely a Kultúra a digitális forradalom idején címet viseli, és amely a nagyjából három évtizedes múltra visszatekintő infokommunikációs revolúció és az azóta eltelt idő kis és nagy történeteit igyekszik dokumentálni. A kötet négy tematikus egységében (Információ, társadalom; Web, archiválás; Pop, kultúra; Tartalom, szolgáltatás), összesen tizennégy tanulmányban foglalkoznak a különböző tudományterületeken tevékenykedő szerzők a magyar nyelvủ internet különböző vonatkozásaival.

Az első tartalmi egység az információhordozó szöveg rendszerezésével és digitalizációjával két tanulmány erejéig is foglalkozik, bemutatva, hogy a tartalmi szempontból megegyező, de formátumát tekintve eltérő szöveg milyen lehetőségeket hordoz a befogadó számára. A technikai fejlődés következtében a nyomtatott szöveg ismételhetőségét és saját ütemü befogadását a digitális szöveg szintaktikai kereshetősége és másolhatósága váltotta, majd a hipertext linkelhetősége és saját irányú befogadása, hogy az adatbázis-transzformációt követően a szemantikus kereshetőség és következtethetőség lehetőségét nyújtsa. Kétségtelen, hogy a technológiai lehetőségek a puszta szöveget egyre intelligensebbé teszik, gyorsabb, egyszerübben hozzáférhető és pontosabb tudással kecsegtetnek, azonban érdemes a fejlődés rohanásából hátra is tekinteni, hogy az út során nem veszítettünk-e el valamit. Megőrizzük-e azon kognitív müveletek képességeit, amelyek a keresést, rendszerezést, megértést szolgálták? Megválaszolandó, aktuális kérdések ezek, amikor már nemcsak az internetes mémek figurázzák ki a ma emberének kognitív képességeit, hanem a tudomány müvelői is vitáznak arról, hogy az információk mennyisége és befogadásának jellegzetességei milyen nem várt következményekkel járnak. A digitális eszközök és tartalmak közönsége egyre kevésbé szegmentálható egyszerü hozzáférési és használati dichotómiákkal. Ma már alig tapasztalhatunk különbséget az olyan alapvető ismérvekben, mint például a nem. Férfiak és nők közel ugyanolyan arányban használják az internetet, sőt a demográfiai jellegzetességek miatt az internet közönségében már többségben vannak a nők. Amikor a társadalom egyre kisebb részét alkotják a távolmaradók, elötérbe kerülnek a tartalomfogyasztási és a felhasználói tudásból fakadó vélt és valós különbségek.

A magyar internet történeteiben ott van az olvasó saját története is. Én a 2000-es évek elején kezdtem dolgozni a Budapesti Műszaki és Gazdaságtudományi Egyetemen müködő Információs Társadalom- és Trendkutató Központban (ITTK), és még abban az időben is volt arra példa, hogy a nem online média 
képviselője egy-egy a világhálóhoz kapcsolódó hír szakértői kommentálása alkalmával őszinte rácsodálkozással kérdezte az ITTK kutatóit az internetről. Így két-három évtizednyi távlatból furcsán hat, ha felidézzük a magyar internet első éveinek mindennapi jellegzetességeit, például az internetről alkotott statikus képet, amikor a nyomtatott lapban rossz szintaktikával vagy egyáltalán, csak külön kérésre jelentettek meg webcímet egy-egy internetes hírrel kapcsolatban. Minden ilyen történet megörzendő, amelyre a digitális tárolókapacitások lehetőséget is biztosítanak, azonban az eredeti források tanulmányozásának lehetősége mégsem feltétlenül adott. Sokat tehetnek az archiválásért az önkéntesen szervezödő közösségi archívumok, amelyre vonatkozóan találunk jó példákat a kötetben. A digitális információk archiválásának egyszerűsége csak első pillantásra az. A könnyedén másolható és manipulálható digitális információ a hiteles megörzés lehetőségének kérdéseit veti fel. Az archiválás folyamatos és hiteles kell legyen ahhoz, hogy a jövőben hozzá lehessen férni az eredeti információkhoz és - ahogy Moldován István írja - „ne sötét digitális középkorként tekintsünk jelenünkre, közelmúltunkra".

A kötet egy-egy villanásként a magyar nyelvű internet és azon belül a magyar nyelvủ közösségi média népszerủ tartalom-előállítóival és -megosztóival foglalkozik. A tanulmányok között helyet kap a motivációs kultúrát ironizáló, kifordító, ún. demotiváló plakátok elemzése. A közösségi média felületei között képet kaphatunk az Omega-rajongók a zenekarral kapcsolatos sajátos, rivalizáló, a mainstream elbeszélésekkel szemben megfogalmazott történeteivel, értelmezéseivel. A TrollFoci történetével, amely kétségtelenül az egyik legsikeresebb magyar közösségi oldal. A nosztalgiát jeleníti meg az olyan retró tematikájú oldalak bemutatása, mint a közösségi szerkesztésü Retronóm és a Szétszedtem project vagy a kilencvenes évek második felében a hazai múvészeti és hálózati kultúrát alakító Artpool, a $C^{3}$ és az Éjjeli Örjárat oldalak.

A kötet utolsó tartalmi egységében helyet kapnak az online hírmédia ikonikus szereplöit, történeteit bemutató írások. Gálik Mihállyal az Origo hírportál piacra lépését és a Magyar Telekomon belüli életét kísérhetjük végig. Az Origo hírportál 1998-ban startolt a Matáv keretei között, és 2015-ben került ki a Magyar Telekom tulajdonából. A tanulmányból megismerhetővé válnak a telekommunikációs vállalat tartalomszolgáltatói motivációi, a portál létrehozásának és piacra bocsátásának szakmai, pénzügyi és politikai vonatkozásai egyaránt. Hasonlóan átfogó szemlélettel mutatja be Tófalvy Tamás az Index átalakulását és az azt övező diskurzust, illetve foglalkozik Botházi Mária az erdélyi magyar online sajtó jellegzetességeivel és függési viszonyaival.

A magyar internet történetei nem kívánja az egész magyar internet történetét elmesélni. Ahogy azt a könyv szerkesztöje is megfogalmazza a bevezetöben, az internetnek „sokféle, párhuzamosan egymás mellett létező változata, kultúrája van”. És valóban, szemlélve az egymást követő írásokat, az olvasó 
különböző nézőpontokat, régi és új történeteket ismerhet meg, amelyek mind értékes adalékként szolgálnak a magyar internet tartalmainak, közönségének ismeretéhez.

(Tófalvy Tamás szerkesztö: A magyar internet történetei. Kultúra a digitális forradalom idején sorozat 2. Budapest: Typotex Kiadó, 2021, 192 o.)

Székely Levente a Budapesti Corvinus Egyetem Kommunikáció és Szociológia Intézet adjunktusa, a Mathias Corvinus Collegium Szociológia Műhely vezetője, az Ifjúságkutató Intézet vezetője 